\title{
Environmental Management Practices and Sustainability of Multinational Companies in South-South, Nigeria
}

\author{
Obamen Joseph \\ Business Management Department \\ University of Nigeria, Enugu Campus, Nigeria \\ Omonona Solomon \\ Business Management Department \\ University of Fort Hare, South Africa \\ Okenwa O. C. Gabriel \\ Johnny Eluka \\ Business Management Department \\ University of Nigeria, Enugu Campus, Nigeria
}

\section{Keywords}

Environmental Management Practices, Environmental Management System Quality Management, Sustainability, Green Technology

\begin{abstract}
This study investigates the effects of environmental management practices on the sustainability of multinational companies in south-south, Nigeria. The specific objectives were to ascertain the effects of total quality management on economic sustainability and to determine the effects of technology option on environmental sustainability. Data were collected from secondary sources, from journal publication, book, unpublished article and thesis, newspapers, and organizations websites. Based on the literature review, the study found out that quality management practices positively affected economic sustainability, and that green technologies positively affected social-environmental sustainability. Therefore, it was concluded that the sustainability of the multinational companies and business environment depends on environmental management practices. The study, therefore, recommended that government should empower the institutions and agencies at all levels responsible for enforcement of environmental laws in line, with section 20 of the 1999 constitution of Federal Republic of Nigeria and that government should compel multinational organizations to adopt green technologies in their operations.
\end{abstract}

Corresponding author: Omonona Solomon

Email address for the corresponding author: omononamise@gmail.com

First submission received: $30^{\text {th }}$ November 2017

Revised submission received: $5^{\text {th }}$ March 2018

Accepted: $18^{\text {th }}$ July 2018

\section{Introduction}

Multinational corporations (MNCs) over the years have been a source of controversy across the world. A typical multinational company (MNC) usually functions with a headquarter that is based in one country, while other facilities are positioned in other countries. Most of the MNC are encouraged by the low wage rates and other environmental factors. They enter host nations in different ways and with different strategies such as exporting licensing or foreign direct investment which are critical steps. The idea of MNCs investing in foreign land is not to better the lives of the host country but to exploit in order to develop the home country with the sole objective of maximization of profit at the lowest reasonable cost. Gilpin (1987) states that the motives of multinational corporations are to secure the least costly production of goods for world markets. This objective might be achieved through obtaining the most effective and efficient area for creation, production or acquiring tax assessment concession from the host 
government. In attaining this feat, MNCs is expected to make contributions to the growth of the host community. For example, in Nigeria, the MNCs transfer technologies, capital, culture of entrepreneurship and increase both investment levels and income of the country; the MNCs improve their immediate environment; generate employment, etc. They stimulate domestic production, enhance efficiency and effectiveness of the production process; they encourage positive responses from local operators (Ezie et al., 2013).

Ozoigbo et al., (2011) states that, presently, multinational corporations have dominated discussion on political economy that the activities of the MNCs in Nigeria have generated a disgusting reaction from many economic theorists like Onimode (1982) who sees MNCs as monsters that have consistently and systematically reduced economic development in various parts of the world. At the same time, they are always also accused of unethical activities such as damaging the environment, social, economic, complicity in human rights abuses, involvement in corruption and pollution. Regardless of whether these allegations are reasonable or not, these entire allegations call for environmental management practices (Bulus et al., 2012). Shrivastave et al., (1995) opines that environmental management is overall the platforms and issues that deal with the internal and external ecology, starting from the point of raw material inputs, transforming process, packaging, to waste disposal. Environmental management practices are conglomeration of organizational activities aiming at reducing resource consumption and improving waste disposal including technological options, product design, and waste management. Hajmohammad (2013) defines environmental management practices as "the level of resources invested in activities and know-how development that lead to pollution reduction at the source," including the application of environmental management systems (e.g. ISO14001), and efforts to recycle materials and reduce waste. These management practices include ecological audits, total quality management, pollution prevention plans, environmental training for employees, complete cost accounting, life-cycle analysis, hiring a designated ecological manager, environmental standards for suppliers, and employee incentive programmes for environmental suggestions.

Bergmiller et al., (2009) believes that environment administration practices (green practices) are these exercises that are enshrine in enhancing environmental performance, which includes improving proficiency, shortening reaction time, cutting down energy consumption, reducing waste and toxic material usage, improving resource utilization, and reducing production costs; all these bring about competitive benefits, business opportunities, and organizational sustainability. Stanwick (1998) and Hart et al., (1996) opine that environmental management practices could improve, not only ecological, but also the economic performance of a company. They stated that companies who have implemented sound ecological management practices over time always achieve good corporate performance, especially in innovation. However, for the purpose of this study, environmental management practices will be considered as waste management, environmental management system, quality management practices, product re-design, technological option, environmental audit, and green image. However, Jiehui et al (2015) asserts that there are three motivational reasons that help organizations to implement environmental management practices.

A company can only be considered to be "legitimate" and avoid penalties if it meets the requirements of the environmental regulation (Hunt and Auster, 1990). Economic interest to bring economic benefits by generating recycling revenue, boosting sales, achieving a first-mover advantage, enhancing social reputation, and improving product quality (Porter, and Linde (1996); and Competitive advantage (Rennings et al., 2006).

While, Boudreau et al., (2005) sees sustainability as a process of realizing progress today without compromising the necessities of the future. The Charter of the Sustainability Committee made by the Board of Directors at Ford concentrates on sustainable growth, which is characterized as "the capacity to address the issues of present stakeholder while considering the requirements of who and what is to come (Ford, 2012). However, accomplishment of sustainability requires the combination of three indicators or measurements which are financial, ecological and social (Rosen et al., 2012). But more recently, attention has been focused on the effective environment management practices. 
Globally, effective environment management practices adopt the use of pollution prevention, green technology, innovation proprietary pollution technology, taking local environmental management law and adoption of International Organization for Standardization (ISO) frameworks such as the ISO14001 series that provide general requirements for business to choose, in addressing various aspects of environmental management (ISO, 2009). International standards covering ecological management practice provide organizations with the elements of an efficient environmental management system. Thus, the implementation of environmental management practices enables multinational companies to improve organizational image, clear/efficient operation, productivity improvement and cost saving, profitability, and competitive product services, and enhanced relationship with stakeholders (May et al., 2010), while Alfred et al., (2009) states that ecological administration is positively connected with organizations' operating performance, as it builds the relative efficiency of input sources, reduces production costs and maximizes the use of organizational assets.

However, in Nigeria, especially the south-south region of the country which plays host to many multinational companies specifically the multinational oil corporations, has over time witnessed a high concentration of industries in the region which according to Ajayi (2011) can be best explained by the valorization of raw agricultural products, natural resources or the treatment of raw materials for export, or through the principle of import substitution adopted by the Nigerian government as their industrial planning strategy. However, the cluster nature of the industries in the region has led to both water and sound pollution in the area.

Yang (2011) was of the opinion that pollution is one of the primary challenges for environmental management practices. Thus, organizations should endeavour to create items and services that decrease contamination, less vitality utilization that required fewer packages (Humphreys et al., 2003). Nevertheless, despite recognizing the growing importance of environmental management in manufacturing processes among multinational organizations, the situation looks different in Nigeria; all through the lifecycle of a product there is a problem concerning the decisions on how to achieve adequate environmental management in companies and selecting the right tools to implement ecological management is still difficult regarding costs and compliance with stakeholders' regulatory requirements (Montabon et al., 2007). While less attention is given to the following aspects of environmental management:

(a) management decisions,

(b) green image,

(c) environmental design,

(d) environmental management system, and

(e) environmental competences, quality management product design, environmental management system, waste management, prevention of pollution, and employee education on environment.

All over the world, much research has been done on corporate environmental management practices. Only a few researchers hold negative perspectives that given evident externality, implementing environmental management may harm an organization's financial advantages or reduce its competitive power. While society profit in short and long run, the organization itself bears all expenses of environmental management practices (Stanwick et al., 1998). However, some companies are unwilling to implement environmental management programmes, risking fines and prosecution, by ignoring or circumventing increasingly strict environmental protection regulations. This affects the performance and sustainability of multinational operations in the southern part of Nigeria in respect to social economic and environmental development.

In addition, company organizational image reduces productivity and increases cost, reduces profitability, and negatively affects the relationship with stakeholders (May et al., 2010), and also depleted natural environment and strain livelihoods which impact business directly as supply chain disruption and lead to loss of many hour efficiencies which affects financial long-term variability and sustainability of firms. Since some researchers are of the view that environmental management practices could only improve the wellbeing of the external environment, therefore, it becomes pertinent to investigate the 
effects of environmental management practices on the sustainability of multinational company in the south, south Nigeria.

\section{Objectives of the Study}

The major objective of the study is to determine the effects of environmental management practices on the sustainability of multinational companies in south-south, Nigeria. However, the specific objectives are to:

ascertain the effects of total quality management on economic sustainability; and to determine the effects of technology option on environmental sustainability.

\section{Review of related literature Environment defined}

There are divergent views about the concept of environment through the contributions of various authors and scholars. Okoh et al (1986) posits two views of perceived environment in the literature. The first is the inter-organizational view, which considers the environment as a collection of persons, groups and other organizations that provides input to, or receives outputs from a local organization. The second consideration is that environment is a set of general, social, economic and technological conditions. Obasan (2001) states that environment is the sum total of the physical, social forces and institutions that are relevant to organizational goal setting and goal attainment which are taken directly into consideration by members of the organization when making business decisions and plans. According to Osuagwu (2001), environment is the totality of the factors that affect, influence, or determine the operations or performance of a business. The environment determines what is possible for the organization to achieve. Above all, environment is the combination of many factors both tangible and non-tangible that provide the lifeblood for the organization's success by providing a market for its products and services and also by serving as a source of resource to others.

\section{Environmental Management Practices}

Environmental management is a purposeful activity that is aimed at improving and maintaining the conditions of an ecological resource affecting human actions. It can also be defined as the process of managing the environmental issues associated with company activities. Ecological management encompasses all the events and technologies necessary to control the environmental performance of governmental and non-governmental organizations and institutions. Kirk (1995) describes ecological management practices as a broad term that deals with different environmental impacts, sustainability, the management of resources, and pollution. In the view of Strydom et al., (2009), who described environmental management as the planning, doing, checking and acting activities of various decisionmakers as they relate to the environment. That means ecological management practice is any action taken by small and large organizations with the aim of minimizing environmental damage. Psomas et al., (2011) is of the view that environmental management is a medium to introduce sustainable development into production processes. While Chang-Hua et al (2013), defined environmental management as an on-going process initiated by management decisions to monitor activities and take the necessary steps to reduce any adverse environmental impacts.

\section{Various Environmental Management Tools Used by Organization}

Garrod et al., (1996) identifies some ecological management tools used by agencies. These tools include environmental reviews, environmental policies, environmental audits, clean technology, and product or process life-cycle assessments. While, Berry et al., (1998) affirmed that organizations that accept a proactive ecological management approach influence the utilization of waste minimization and avoidance, to request side administration, plan for the environment, item stewardship, and full-cost (ecological) bookkeeping as a significant aspect of an organized way to deal with their environmental impact. However, the most famous tool used in environmental management is the environmental management system. 
In addition, Spellerberg et al., (2004) described environmental management framework as a formalized, harmonized process or structure that helps organizations to address their ecological impacts by the method of policy development and implementation, distribution of obligations and assets, and the consistent change of practices and performance given through observation and evaluation. Darnall et al., (2008) supported this definition by asserting that an ecological management framework comprises of a gathering of internal strategies, assessments, plans, and implementation activities that influence the business overall and its relationship with the environment. Rowland-Jones (1996) also expressly stated that an environmental management system requires a business to distinguish and enroll its ecological impacts while advancing persistent ecological change. Expressed unexpectedly, an ecological management framework is a management framework that is planned to urge business to control its environmental effects and lessen such as suggestions on an on-going basis. However, Sadgrove (1997) reiterated this by defining an environmental management system as a comprehensive, methodical, premeditated, regular, and documented method for managing a company's environmental impacts.

\section{Environmental Auditing}

Environmental auditing is a tool for checking whether a firm or an organization is doing what it should be doing. For instance, a legislative compliance audit checks that those activities of the company covered by environmental legislation (i.e., what it is doing) comply with that legislation (i.e., what it should be doing). An environmental audit will tell a firm or an organization whether its waste management practices (i.e., what it is doing) conform to the industry sector best practice guidelines it has committed itself to following (i.e., what it should be doing).

Environmental auditing is the practice of comparing environmental regulatory and management requirements against the operational and management performance record of a facility by evaluating such records and systems against a set of predetermined standards; (Prince \& Nelson, 1996) said it is a systematic, periodical evaluation of a company's environmental organisation, performance, and systems against pre-determined standards.

The audit may be carried out by either company or external auditors and must be consistent with ISO 14011. The check must address a range of issues listed in Annex I(C), including assessment, control, and reduction of environmental impacts; raw energy, materials and water management and savings; evaluation, control and reduction of noise; product planning, including transportation, use and disposal; the environmental performance and practices and contractors, subcontractors and suppliers; prevention and limitation of ecological accidents; emergency procedures; and staff information and training on environmental issues. Annex II sets out requirements for the audit process, including audit objectives, reports, follow-up, and frequency. The audit results and procedures must be verified by an independent, accredited verifier (Wälde, 1992).

\section{Environmental Reviews}

An environmental review is a process of reviewing a project and its potential environmental impacts to determine whether it meets federal, state, and local environmental standards

\section{Environmental Policies}

The environmental policy is a document which sets out the overall aims and intentions of a firm/company concerning the environment. Developing an environmental policy is often the first step taken by firms/companies who wish to undertake ecological management. An ecological system signals a commitment to environmental management and can prepare the way for further ecological management activities. In addition, an environmental policy provides a sense of direction for a company and shows that it is committed to responsibly managing its environmental affairs. The system should be endorsed by the company's senior management and should be publicly available. It should be an integral part of the business strategy and be compatible with company's other policies (e.g., on quality and health and safety) (National Environment Commission, 2011). 


\section{Product or Process Life-Cycle Assessments}

Life-Cycle Assessment (LCA) is considered a systematic tool used for evaluating the environmental impacts occurring throughout the entire life-cycle of a product, process or activity (Hertwich, 2005). This 'cradle-to-grave' approach leads to insight into the overall performance and the relative contributions of the different stages in its lifetime. However, life -cycle assessment is essential to sustainable consumption and production as well as development, as it involves the evaluation of the environmental impacts of a product system through all the stages of its life-cycle. It is about going beyond the traditional focus on the production site and manufacturing processes, to include the environmental, social, and economic impact of a product over its entire life-cycle (Koroneos, 2013; UNEP, 2009). The primary goals of life-cycle assessment are to reduce a product's resource use and emissions to the environment as well as improve its socio-economic performance throughout its life-cycle. This may facilitate links between the economic, social and environmental dimensions within an organization and throughout its entire value chain. The terms of "life-cycle analysis," "life-cycle approach," "cradle to grave analysis" or ecobalance, stand for a rapidly emerging family of tools and techniques designed to help in environmental management and, longer term, in sustainable development (UNEP, 2004).

\section{Sustainability}

The word sustainability has been a household word used and has become widespread when discussing environmental and business issues. Filho (2000) states that the word sustainability was used initially in the 1970s to refer to the management of forests. Filho (2000) argues that the sustainability has multiple meanings including long-term, durable, sound and systematic. At its most basic level, the concept of sustainability is the philosophy that humankind should live in harmony with nature and with society (Mebratu, 1998). Filho (2000) further defines sustainability as a developmental process which enables countries to progress economically and socially without adversely affecting their environmental resources while being ethically acceptable, morally fair and financially sound. However, Solow (1991); Costanza \& Patten (1995) critique the concept of sustainability and argue that it should not only refer to efforts to preserve the environment, but that it is a much broader term which is also important on the production side and relates to use of resources as well as minimizing waste. Solow (1991) opines that sustainability is often confused with green and that sustainability is a vague concept. He proposes that humanity must leave the world as we found it, but also argues that such an idea in the definition is unfeasible and not even desirable. Costanza \& Patten (1995), suggest that for any system to achieve its goal there is a set time frame, but for the concept of sustainability, there is no time frame because once completed, sustainability needs to be maintained forever. The authors further explain that nothing lasts forever, not even the universe. They argue that sustainability cannot be measured, nor can it be assigned a time frame. Sustainability can only be said to be achieved if the system attains its normal maximum life span because that would indicate that resource consumption and waste had been optimal (Solow, 1991; Costanza \& Patten, 1995). Karpagam, (2008) argues that most definitions are however based upon the thought communicated by the Brundtland Commission which conceptualized sustainability development as an advancement that addresses the issues of the present generation without bargaining the capacity of the future generations to solve their particular problems (Barbier; cited to in Karpagam, 2008)

\section{Measurement of Sustainability}

There are three essential components of sustainable development: economic, social and the environment. The financial component of sustainability requires that societies pursue growth paths that generate an optimal flow of income while maintaining their basic stock of human-made capital, human capital and natural capital. Economic sustainability also requires internalizing all costs including the environmental costs associated with production and consumption. The three central objectives of financial sustainability are: to expand the creation of product and services, fulfill the fundamental needs or decrease poverty and move forward. The social measurement of sustainability improvement is based on the standards of equity and uniformity. For development to be sustainable over an expanded period, riches, assets and opportunity ought to be fairly shared. Social value suggests rise to chances to education 
and commitment to society in regard to assorted social variety, social equity, sexual orientation uniformity and open participation. The natural part similarly requests sustainable asset utilization, productive sink capacity and upkeep of a load of normal capital, i.e., the environment ought to have the ability to play out its three roles efficiently and continuously with the goal that environment security and flexibility are not influenced.

\section{Total Quality Management}

Total quality management has been defined by different authors' based on the industry, but they all focused on common customer satisfaction without damaging the environment. Sashkin \& Kiser (1993), define Total Quality Management as a means by which the organization 's culture is defined, and supports the constant attainment of customer satisfaction through an integrated system of tools, techniques, and training. Ugboro \& Obeng, (2000) see total quality management as a process and continuous improvement, top management leadership commitment to the goal of customer satisfaction, employee empowerment, and customer focus. The International Standard ISO 8402, quality management and quality assurance terminology defines total quality management as the management approach of an organization, that centered on quality, based on the participation of all its stakeholder and aiming at longterm success through client fulfillment, and benefits to all groups of the organization and to the society (Ljungstrom \& Klefsjo, 2002). Temtime \& Solomon (2002) express that total quality management looks for persistent improvement like all procedures, individuals, items, and services of an organization. Component of TQM that may be specifically relevant to sustainable management practice which of course is also imbedded in the six-sigma quality management includes the following:

Continuous Improvement: Employees training, systems measurements, continuous quality audits and benchmarking must be put in place to ensure sustainability of TQM.

Customer Focus: As the saying goes "customer is the king", therefore, for genuine and sustainable growth, the customer complaints handling, customer feedback systems, customer retention interventions and market-based research must be properly structured to maintain the quality of service rendered to the customers.

Top management commitment: Quality vision, resources allocation, quality leadership and quality policies must not be compromised.

\section{Technology Option}

Information Communication Technology (ICT) is the use of computers and broadcast communications hardware to store, recovers, transmit and control information (Daintith, 2009). Information communication technologies has affected the community and its surroundings in some ways. In many organizations, technology has helped develop more advanced environmental problems including environmental pollution. Numerous technology procedures deliver undesirable product known as contamination, and exhaust natural assets, to the impediment of earth condition. A different implementation of technology impacts the estimations of society and innovation frequently brings up moral issues. Environmental technology courses situated towards creating electronic, electrical or electro technology graduates equipped for creating gadgets, and curious-ready to monitor, measure, model ecological control effect, including observing and overseeing energy generation from infinite sources, and creating novel energy (Kwazo et al., 2014).

Ecological technology (envirotech), green innovation (Greentech) or clean innovation (cleantech) is the use of or more of environmental science, green science, natural observing and electronic gadgets to monitor, model and save the natural environment and assets, and to check the adverse effects of human involvement. The term is also used to describe sustainable energy generation technologies such as photovoltaic, wind turbines, bioreactors, etc. Sustainable development is the core of environmental technologies. The term "green technology" is also used to describe a class of electronic devices that can promote sustainable management of resources (Taesler, 1991).

Technologies influence people and also other creature's species capacity to control and adjust to their everyday environment (Hassan, 2013). The case of technology incorporates construction innovation, 
medical /wellbeing innovation, biotechnology, green innovation, nanotechnology and Information Communication Technology (ICT), and so forth. Ghanshyam, (2015) states that the selection and utilization of green innovations include the use of natural advancements for observing and evaluation, contamination anticipation and control, and remediation and reclamation. Observing and evaluation techniques are utilized to gauge and track the state of the environment including the release of natural or anthropogenic materials of a harmful nature. Prevention innovation avoids the production of environmentally hazardous substances or alter human activities in ways that minimize damage to the environment; it encompasses product substitution or the redesign of an entire production process rather than using new pieces of equipment. Control innovation renders dangerous substances innocuous before they enter the earth. Remediation and reclamation innovations epitomize techniques intended to enhance the state of natural systems degraded through naturally induced or anthropogenic impacts (Ghanshyam, 2015).

\section{Empirical Review}

Kelly \& Florence (2014) examined environmental management and sustainable development in the Niger Delta region of Nigeria. The specific objectives of the study were to investigate the relationship between commitments by Federal Government to environmental management policies and sustainable development, and to assess the relationship between true development agenda and sustainable development. The study adopted a survey design. The data were obtained from both primary and secondary sources. The primary data were collected from focus group discussions without evidence of the publication; the secondary data were obtained from relevant textbooks, journals, and other documents. The findings of the study showed that environmental management policy gaps, inadequate commitment to the implementation of environmental policies, poor environmental management practices as well as weak development agenda are constraining factors to sustainable development in the Niger Delta. The study recommended that agenda that is environmental, socially and economically benign and synthetic and integrated environmental management principles and practices that are in tandem with sustainable development should be made and implemented.

Ogbari \& Borishade, (2015) carried out a study to examine the relationship between total quality management and customer satisfaction in service industries. The specific objectives were to evaluate the relationship between top management commitments and customer retentions; to examine the influence of organizational reputation on customer's continuous patronage. The study adopted a quantitative survey. Data were collected from secondary sources. The study found out that strong relationship exists between total quality management and customer satisfaction in the achievement of organizational goals especially in the current dispensation of globalization and stiff competitions, that overall quality management and customer satisfaction have increased steadily over a period in some service industries, but top management still have much to do in order to entrench TQM and customer satisfaction as policies in their organizations. The study concluded that total quality management practices have a positive impact on customer satisfaction. The study recommended a holistic adoption of TQM and customer services tenets in the organization.

Rosemarie (2016) carried out a study to establish the effect of quality management practices on the performance of manufacturing firms in Kenya. The specific objectives were: to establish the impact of continuous improvement on firm performance; to assess the influence of customer-focus on firm performance and to assess the extent to which the operating environment moderates the relationship between quality management practices and performance. The study used both descriptive and explanatory research design. The study used primary data through questionnaires. The validity of the instruments was done through the face, and content validity. Data were analyzed using Multiple Linear Regression. The study found out that continuous improvement had a positive and significant effect on performance. Customer-focus was found to be significant in explaining the variation of performance, and top management commitment was seen to have a substantial impact on performance. The study recommended that the organizations should be committed in providing quality strategic direction concerning management practices, which should be aligned to the firms' objectives. Augus (2000) said 
that implementing total quality management could improve the company's customer satisfaction. Ingram \& Chung (1997) explained that total quality management practices could increase customer satisfaction in the healthcare industry. Moreover, Haisin (2001) added that complete quality management could improve the competitiveness of the hospital in Thailand. Aghazadeh (2002) also agreed that a total quality management practice is important for business. Many researchers have studied the impact of overall quality management practices on customer satisfaction in the service and manufacturing industries. Kanji (1999) reported that total quality management could increase customer satisfaction in United Kingdom Universities.

Kwazo, Muhammad, Tafida, \& Mohammed (2014) investigated Environmental Impact of Technologies and found out that technologies have affected society and its surroundings including the environment in some ways. They found out that in many countries, technologies have helped to develop more advanced environmental problems including global warming. Many technological processes produce unwanted by-products, known as pollution, and depleted natural resources, to the detriment of earth's environment. He recommended that there is need to promote environmentally sound practices globally by strictly adhering to a green environment and there is a need for the implementation of environmental-wide green procurements strategies concerning technologies acquisition, use, and disposal. Some studies have been carried out by industry, organizations, and researchers exploring the idea of ICT contribution to solving environmental problems. (Mingay (2007); Buttazoni (2008); Coroama and Hilty (2009); Mickoleit (2010); GeSi (2012)). ICT is suggested to be able to contribute to sustainable development and reduction of environmental impacts in some ways, such as, e.g., replacing products, intensifying use of products/space/transport, increasing efficiency of processes/activities, informing consumption choices (Höjer 2015). It has been argued that to ensure the minimization of adverse and the facilitation of positive effects of ICT use; it needs to be supported by incentives or regulation (Berkhout and Hertin 2004; Höjer, 2015). Ghanshyam (2015) suggested that green technologies encompass various aspects of technology which help us reduce the human impact on the environment and create ways of sustainable development. Social equitability, economic feasibility, and sustainability are the key parameters for green technologies. It can efficiently change waste pattern and production in a way that it does not harm the planet and we can go green.

Abhijeet and Rahul (2014) examined green technology for sustainable urban life. They stated that human civilization uses technology for supporting day to day activities of urban life. New technologies are more efficient and environmentally friendly due to increased awareness of energy management. They found out that the adoption of technology is limited and has adverse effects on the environment and human civilization. They concluded that application of new technologies which are environmental friendly for supporting day to day activities of an urban lifestyle is a prerequisite for sustainability.

\section{Methodology}

This paper adopted an empirical survey essay method which made use of the secondary method of data collection that involved the sorting and analyzing of past related study gotten from published journal, thesis, unpublished journal, books newspaper and online textbooks.

\section{Result \& Discussion}

Operations of the multinational firm based on sustainable development principles demand the stimulation of action which can lead to a better management of the environmental aspect related to adverse generated effect, optimization of the production processes to develop sustainable production and consumption process. In doing this, the managerial implication is that managers at all level should realize that environmental management practices cannot only lead to external ecological improvement but can also lead to competitive organizational advantages, image management and promote technological innovation called green technology which can reduce internal and external pollution and create the firstmover advantage and improve social, economic and environmental sustainability. Due to worsening air quality, soil contamination, water pollution and other environmental issues, the multinational company is 
faced with increasing pressure of ecological protection by society, governments, and other stakeholders to implement ISO1401 document and other international and local environmental law.

However, many multinational companies do not know how to adopt environmental management practices efficiently and implement it in line with international best practices. This study suggests that, compared with passive and end-of-pipe treatment, proactive and preventive ecological management practices could more efficiently promote technological innovation performance. Since the costs of environmental management practices are high, while the benefits are vast but can only be realized in the future. A thoughtless executive who wants to minimize cost with a mindset of instant gratification will tend to postpone investments in environmental management practices. In actuality, ecological management practices such as the application of ecological management assessment tools (such as lifecycle assessment, quality management, technological option green technology ecological auditing, ISO14001), establishing ecological performance targets, publicly disclosing environmental performance and training the staff on environmental protection could provide huge gains through the first-mover advantage.

However, it was discovered in the findings that the importance of environmental management practices in the business environment could not be overemphasized to national green management, that total quality management positively affected economic sustainability, this is in line with Nguyen (2018) who studied on the relationship between quality management practices and sustainability performance, where he opined that there are four quality management practices that have significant positive impact on sustainability performance: top management support for quality management, design for quality, quality data and reporting, and continuous improvement. In addition, Sadikoglu et al (2014), found out that TQM positively and meaningfully affects the organizational learning and that organizational learning has a significant effect on the organizational innovation, but TQM has no positive and meaningful effect on the organizational innovation.

Lastly, it was established that green technologies positively affected social-environmental sustainability which is in line with the studies of Sezen (2013) and Kucukoglu (2015) that the green manufacturing applications have a significant positive impact on environmental performance and also green innovation activities have significant effect on an organization environmental performance and competitive advantage respectively.

\section{Conclusion}

This study sorts for the effects of environmental management practices on the sustainability of multinational companies in south-south, Nigeria. However, environmental management practices (green methods), as stated earlier, is an activity which is aimed at improving environmental performance, including improving efficiency, shortening response time, cutting down energy consumption, reducing waste and toxic material usage through the implementation of the six-sigma quality management and application of quality control. Hence, in line with the findings, the study concludes that the sustainability of the multinational companies and its business environment largely depends on quality of environmental management practices. This, however, does not rob this study of its generalization. Hence, the frontier of this study could be expanded by investigating the environmental Management Practices and the Sustainability of the service industry.

\section{Recommendations}

That government should empower the institutions and agencies at all levels responsible for enforcement of environmental laws in line with section 20 of the 1999 constitution of Federal Republic of Nigeria, that government should compel multinational organizations to adopt green technologies in its operations.

Workshops should be organized to sensitize the management of multinational company on the need to adopt TQM. 


\section{References}

Abhijeet B \& Rahul M. D. (2014). Green Technology for Sustainability. Urban Life Research in Science and Technology, 6(1), 04-08.

Adgrove, K. (1992). The Green Manager's Handbook, Gower Press.

Aghazadeh, S. (2002). "Implementation of total quality management in the managed care industry", The Total Quality Management Magazine, 14(2), 79-91.

Ajayi, D (2011). Nigeria's industrial development: issues and challenges in the new millennium. WIT Transactions on Ecology and the Environment, Vol 150, WIT Press.

Alfred, A. M., \& Adam, R. F. (2009). Green management matters regardless. Academy of Management Perspectives, 23(3), $17-26$.

Berkhout, F., \& J. Hertin. (2004). De-materialising and re-materialising: digital technologies and the environment. Futures $36(8)$, 903-920.

Berry, M. A., \& Rondinelli, D. A. (1998). Proactive corporate environmental management: A new industrial revolution. Academy of Management Perspectives, 12(2), 38-50.

Boudreau, J. \& Ramstad, P. (2005). Talentship, talent segmentation, and sustainability: A new HR decision science paradigm for a new strategy definition. Human Resource Management, 44(2), 129-136.

Bulus, H. \& Ango, N.A (2012). Multinational Companies Corporate Social Responsibility Performance in Lagos State, Nigeria: A Quantitative Analysis. European Journal of Globalization and Development Research, 5(1), 4-14.

Buttazoni, M. (2008). Potential global CO2 emission reductions from ICT use: Identifying and assessing the opportunities to reduce the first billion tonnes of $\mathrm{CO} 2$ emissions. Solna: World Wildlife Fund Sweden.

Chang-Hua, Y. Chien-Yu, C. \& Hsiu-Yu, T. (2013). Perceptions of environmental management and employee job attitudes in hotel firms. Journal of Human Resources in Hospitality and Tourism, 12(2), 155-174.

Coroama, V. \& L. M. Hilty. (2009). Energy consumed vs. energy saved by ICT: A closer look. Paper read at environmental informatics and industrial environmental protection: concepts, methods and tools. 23rd International Conference on Informatics for Environmental Protection, Berlin.

Costanza, R., d'Arge, R., De Groot, R., Farber, S., Grasso, M., Hannon, B., ... \& Raskin, R. G. (1997). The value of the world's ecosystem services and natural capital. nature, 387(6630), 253.

Daintith, J. (2009). A dictionary of Physics. 6th Edition, Oxford University Press, Oxford, UK.

Darnall, N., Rigling Gallagher, D., Andrews, R. N., \& Amaral, D. (2000). Environmental management systems: opportunities for improved environmental and business strategy? Environmental Quality Management, 9(3), 1-9.

Donnelly, K., Beckett-Furnell, Z., Traeger, S., Okrasinski, T \& Holman, S. (2006). Eco-design implemented through a product-based environmental management system. Journal of Cleaner Production, 14(15), 1357-1367. doi: 10.1016/j.jclepro.2005.11.029.

Ezie, O. \& Osuagwu, G. O. (2013). Multinational corporations and the Nigerian economy. International Journal of Academic Research in Business and Social Sciences, 3(4), 359-369

Filho, W. L. (1997). Integrating environmental education and environmental management," Environmental Management and Health, 8(4), 133-135.

Ford, J. D., Ford, L. W., \& McNamara, R. T. (2002). Resistance and the background conversations of change. Journal of organizational change management, 15(2), 105-121.

Garrod, B., \& Chadwick, P. (1996). Environmental management and business strategy: towards a new strategic paradigm. Futures, 28(1), 37-50. http://dx.doi.org/10.1016/0016-3287(95)00076-3

Ghanshyam D, S. (2015). Advantages of green technology. International Journal of Research, 3(2), 1-5.

Gilpin, R. (1987). The Political Economy of International Relations. Princeton University Press, Princeton

Gonzalez, P., Sarkis, J \& Diaz, B. (2008). Environmental Management System Certification and its Influence on Corporate Practices. Evidence from the Automotive Industry. International Journal of Operations and Production Management, 28(11), 10211041. http://dx.doi.org/10.1108/01443570810910179.

Hajmohammad, S.; Vachon, S.; Klassen, R.D \& Gavronski, I. Lean management and supply management: Their roles in green practices and performance. J. Clean. Prod. 2013, 39, 312-320.

Hart, S.L. \& Ahuja, G. Does it pay to be green? An empirical examination of the relationship between emission reduction and firm performance. Bus. Strategy Environ. 5(6), 30-37.

Hasin, M.A.A., Seeluangsawat, R. \& Shareef, M.A. (2001). Statistical measures of customer satisfaction for health care quality assurance: a case study. International Journal of Health Care Quality Assurance, 14(1), 6-13.

Hertwich, E. G. (2005). Consumption and the rebound effect: An industrial ecology perspective. Journal of industrial ecology, 9(1-2), 85-98.

Höjer, M., A. Moberg, \& Henriksson, G (2015). Digitalisering och hållbar konsumtion. Stockholm: Naturvårdsverket, 66. 
Humphreys, P. K., Wong, Y. K., \& Chan, F. T. S. (2003). Integrating environmental criteria into the supplier selection process. Journal of Materials Processing Technology, 138(1/3), 349-356. doi:10.1016/S0924-0136(03)00097-9.

Hunt, C.B.; (1990). Auster, E.R. Proactive environmental management: Avoiding the toxic trap. MIT Sloan Manag. Rev. 31(6), 7-18.

Ingram, B.L. \& Chung, R.S. (1997). Client satisfaction data and improvement planning in management of mental health care organization. Health Care Management Review, 22(3), 40-52.

Ingram, B.L. and Chung, R.S. (1997), "Client satisfaction data and improvement planning in management mental health care organization", Health care management review, Vol. 22 No. 3, pp. 40-52

ISO, (2009). International standards organisation. Available from internet: http:/ / www.iso.org.

Jiehui Y, Qinglan H, Juanmei Z, \& Chunlin Y. (2015). The Influence of Environmental Management Practices and Supply Chain Integration on Technological Innovation Performance: Evidence from China's Manufacturing Industry. Journal of sustainability 7(2), 1-20.

Kelly B, O \& Florence O., N (214) Environmental Management and Sustainable Development in Nigeria's Niger Delta. Journal of Economics and Sustainable Development, 5(26), 1-6.

Kielstra, P. (2008). Doing Good: Business and the Sustainability Challenge (online). Economist Intelligence Unit Report. Available at www.eiu.com.

Kirk, D. (1995). "Environmental management in hotels," International Journal of Contemporary Hospitality Management, 7(6), 3-8, 1995.

Koroneos, C. J., Achillas, C., Moussiopoulos, N., \& Nanaki, E. A. (2013). Life cycle thinking in the use of natural resources. Open Environmental Sciences, 7(1).

Kucukoglu M.T \& Pinar R.I (2015). Positive Influences of Green Innovation on Company Performance. Procedia - Social and Behavioral Sciences 195 (2015) 1232 - 1237.

Kwazo H. A., Muhammad M. U., Tafida G. M. \& Mohammed, S. (2014) Environmental Impact of Technologies. Academic Journal of Interdisciplinary Studies, 3 (7), 3-4.

Ljungstrom, M., \& Klefsjo, B. (2002). Implementation obstacles for a work development-oriented. Total Quality Management strategy. Total Quality Management, 13(6), 621-634.

Mebratu, D., 1998. Sustainability and sustainable development: Historical and conceptual review. Environ. Impact Assess. Rev., 18: 493-520

Mingay, S. (2007). Green IT: the new industry shock wave. Gartner RAS Research Note G 153703:2007.

Montabon, J., Sroufe, R., \& Narasimhan, R. (2007). An examination of corporate reporting environmental management and firm performance. Journal of Operations Management, 25(5), 998-1014. doi: 10.1016/j.jom.2006.10.003.

Obasan, K. (2001), “Small Business Management: An Entrepreneurial Approach", Lagos Higher Education Books Publishers.

Ogbari, Mercy, Borishade, \& Taiye T. (2015). Strategic imperatives of total quality management and customer satisfaction in organizational sustainability. International Journal of Academic Research in Business and Social Sciences, 5(4), 1-22.

Okoh, P.E. and J.C., Munene, (1986). “The Organisation Dynamics, Environment Size, Managerial Values and Decision Choice", Nigeria.

Onimode, B. (1982). Imperialism and underdevelopment in Nigeria: the dialectics of mass poverty, London: Zed Press; Westport, Conn., U.S.A: U.S. distributor, L. Hill.

Osuagwu, G, O \& Ezie O. (2013). Multinational Corporations and the Nigerian Economy. International Journal of Academic Research in Business and Social Sciences, 3(4), 1-11.

Osuagwu, L. (2001), “Small Business and Entrepreneurship Management”, Lagos Grey Resources Limited.

Ozoigbo, B. I \& Chukuezi, C. O. (2011). The Impact of Multinational Corporations on the Nigerian Economy. European Journal of Social Sciences, 19(3), 2-9.

Prince W \& Nelson D. (1996). Developing an environmental model: piecing together the growing diversity of international environmental standards and agenda affecting mining companies. Colo J Int'l Envt L and Pol'y 247 at 292.

Psomas, E. L. Fotopoulos, C. V \& Kafetzopoulos, D. P. (2011). Motives, difficulties and benefits in implementing the ISO 14001 Environmental Management System. Management of Environmental Quality: An International Journal, 22(4), 502-521.

Rennings, K.; Ziegler, A.; Ankele, K. \& Hoffmann, E. (2006). The influence of different characteristics of the EU environmental management and auditing scheme on technological, environmental innovations and economic performance. Ecol. Econ. 57(6), 45-59.

Rosemarie W. W. (2016). Quality management practices and firm performance among manufacturing firms in Kenya. A Thesis Submitted to the School of Business in Partial Fulfillment for the Award of the Degree of Doctor of Philosophy in Business Administration (Human Resource Management) of Kenyatta University. 
Rowland-Jones, R. Pryde M, \& M. Cresser, (2005). An evaluation of current environmental management systems as indicators of environmental performance. Management of Environmental Quality: An International Journal, 16(3), 211-219.

Sadgrove, K. (1992). The Green Manager's Handbook, Gower Press.

Sashkin, M., \& Kiser, K. (1993). Putting total quality management to work. San Francisco: Berrett-Koehler.

Savage, G. T., Nix, T. W., Whitehead, C. J., \& Blair, J. D. (1991). Strategies for assessing and managing organizational stakeholders. Academy of management perspectives, 5(2), 61-75.

Sebhatu, S. P., \& Enquist, B. (2007). ISO14001 as a Driving Force for Sustainable Development and Value Creation. The Total Quality Management Magazine, 19(5), 468-482. http:/ /dx.doi.org/10.1108/09544780710817883.

Sezen B and Yildiz C (2013) Effects of green manufacturing and eco-innovation on sustainability performance .9th International Strategic Management Conference. Procedia - Social and Behavioral Sciences 154 - 163.

Shrivastava, P \& Hart, S. (2007). Creating sustainable corporations. Bus. Strategy Environ. 1995, 4, 154-165. Bergmiller, G.G.; McCright, P.R. Parallel Models for Lean and Green Operations. Available online: www.eiu.com.

Solow, R. (1991). Sustainability: An economist's perspective. The Eighteenth J. Seward Johnson Lecture. Woods Hole, MA: Woods Hole Oceanographic Institution

Stanwick, P.A. \& Stanwick, S.D. (1998). The relationship between corporate social performance, and organizational size, financial performance, and environmental performance: An empirical examination. J. Bus. Ethics, 17, 195204.

Strydom H. A. \& King N. D., (2009). Environmental Management in South Africa, 2nd ed. Cape Town: Juta.

Temtime, Z \& Solomon, G. H. (2002). Total quality management and the planning behaviour of SMEs in developing economies. Total Quality Management Magazine, 14(4), 181-191.

Ugboro, I. O. \& Obeng, K. (2000) Top management leadership, employee empowerment, job satisfaction, and customer satisfaction in TQM organizations: an empirical study, Journal of Quality Management, 5, pp.247-272

Yang, C. C., Yang, K. J. \& Peng, S. Y. (2011). Exploration strategies and key activities for a system of environmental management. Total Quality Management, 22(11), 1179-1194. doi:10.1080/14783363.2011.603201.

Zubir FM, \& Habidin FN. (2012). The development of sustainable manufacturing practices and sustainability performance in Malaysian automotive industry. Journal of Economics and Sustainability Development. 5(4), 1-22. 